\title{
A VAJDAHUNYADVÁR MINT KÖRNYEZETI NEVELÉSI SZÍNTÉR
}

\section{Radics Boglárka}

Magyar Mezőgazdasági Múzeum, Budapest

\section{Bevezetés}

2002. december 20-án az ENSZ Közgyülése a 2005-2014 közötti időszakot a Nemzetközi Fenntarthatóságra Oktatás Évtizedének nyilvánította. Ezt figyelembe véve a Magyar Mezőgazdasági Múzeum elkötelezetten támogatja az élethosszig tartó tanulást és hangsúlyt fektet a környezeti nevelés szemléletének terjesztésére, igyekszik különböző közművelődési módszerekkel megszólítani mindenkit, aki fogékony a tradíciókra és a természet szépségeire. 1983-tól befogadóhelye a Liget Oktatóközpontnak, ami a Környezet- és Természetvédelmi Oktatóközpontok Országos Szövetségének (KOKOSZ) tagja, és a témába vágó pályázatok kiírásával, rendezvények szervezésével, zuglói iskolákkal és óvodákkal történő együttmüködésekkel, a múzeum gyüjteményeire, a kiállítások anyagára épülő múzeumpedagógiai és drámapedagógiai foglalkozások tartásával ennek a környezettudatosságra nevelésnek a zászlóvivője és tökéletes színtere.

\section{A helyszín története}

De ne szaladjunk ennyire elöre! Kezdjük a helyszín történetével, amely már önmagában is magyarázatot ad a Magyar Mezőgazdasági Múzeumnak a környezeti nevelés iránti fogékonyságára, s ezen belül különböztessük meg a természetes és az épített környezetet!

\section{A természetes környezet}

A múzeumnak otthont adó Vajdahunyadvár Budapest szívében, a József nádor által a lepusztult Városliget rendezésére, a parkosításra és a Széchenyi-sziget kialakítására 1808-ban kiírt pályázat során helyrehozott területen áll. A ligetet pihenésre, szórakozásra használták és használják a városiak, hol silány mulatozási célból vurstlikkal és akrobatákkal, hol pedig az elegáns föurak lovaskocsikázásának színtereként, napjainkban pedig múzeumaival, állatkertjével kellemes hétvégi kikapcsolódási helyszínként.

\section{Az épített környezet}

Az 1896-os Millenniumi Kiállítás megrendezésének ötletével egy időben merült föl, hogy a Városliget legyen a világkiállítás és a nagyszabású ünnepségsorozatok helyszíne. Az ehhez kapcsolódó egyik építmény, a későbbiekben Vajdahunyadvárnak, akkor Történelmi Épületegyüttesnek nevezett épület megépítéséről szintén egy pályázat döntött, melyet Alpár Ignác nyert el. 
Az építész alkotta meseszerü, de nagyon is átgondolt épületegyüttes a középkori várakat, palotákat és egyházi építményeket a különböző korok jellegzetes stílusjegyei szerint, egész történelmünkön végigvezetve mutatja be. A cél pedig pontosan ez volt, ugyanis a millennium nagyszabású ünnepségére, a magyar nép történelmét bemutató tárgyak közszemlére tételéhez egy kiállítási csarnok szükségeltetett. Az ehhez kapcsolódó építészeti pályázat kiírásának idézete a következő:

„A történelmi kiállítási épület architektúrája úgy tervezendő, hogy az a hazánkban eddig dívott főbb építészeti stílusokat - tehát a románt, a csúcsíveset és a renessaince-ot és az utóbbinak válfajait: a barokkot és rokokót - egészben véve szellemükben, részleteikben pedig nevezetesebb hazai müemlékeink hü utánzataiban tüntesse föl. Kiköttetik továbbá, hogy az épület egyes részeinek csoportosítása lehetőleg festői legyen és a különböző stílusokban tervezett föbb épület-csoportokat alkalmatos átmenetek kössék össze egymással anélkül, hogy az összbenyomást színpadiassá tennék. Általában az épület már külsőleg is általános érdeklődést keltsen föl a látogató közönségben.” (Balázs és Oroszi, 1996. 12. o.)

Egyetérthetünk abban, hogy ez sikerült, s voltaképpen egy várméretü kiállítási tárgyban jött létre egy másik kiállítás. Az így elkészült épületegyüttes történelmünk sokszínűségére mutat rá, a legkülönbözőbb stílusokat felvonultató, ám mégis harmonikus összeépítések és az épületszobrászati elemek tervezése pedig az építész fantáziáját dicsérik.

Nem elhanyagolható információ, hogy a Vajdahunyadvárat kétszer építették föl: először magára a millenniumi kiállításra készítették el fából és habarcsból, majd a kiállítás 1896. őszi bezárását követően Darányi Ignác, akkori földmüvelésügyi miniszter megalapította a Magyar Mezőgazdasági Múzeumot és azt helyeztette el benne. Néhány évvel ezután az épület megrogyott, s az életveszélyessé nyilvánítását követően ismét Darányi Ignác neve merül föl, mint múzeummegmentő, ugyanis ő győzte meg az országgyülést a múzeumnak otthont adó épület időtálló anyagokból történő, újbóli, másodszori megépítésének szükségességéről.

\section{A környezeti nevelés története és eredményei}

Ezután a hosszúra nyưlt, a helyszín történetét bemutató bevezető után az itt folyó szakmai munkára, a környezeti nevelés történetére is pillantsunk rá!

\section{Oktatóközpont}

A Magyar Mezőgazdasági Múzeum 1983 óta ad otthont a Liget Oktatóközpontnak, mely szervezet célja a környezeti nevelés, az ökológiai kultúra terjesztése. Az oktatóközpont 1996-tól a KOKOSZ tagja. A határon túl a szervezet a Környezetés Természetvédelmi Oktatóközpontok Országos Szövetségének külkapcsolatai által a székelykeresztúri pedagógusokkal ápol munkakapcsolatot az Óvodásokkal a Természet Megóvásáért Közhasznú Egyesülettel együttmüködve. Az oktatóközpont tevékenysége változatos, éppen úgy szervez kamara kiállításokat és ír ki 
pályázatokat, mint ahogy részt vesz továbbképzések és konferenciák lebonyolításában.

\section{Diákpályázat}

Múzeumunk először 1970-től 2004-ig írta ki fiataloknak szóló pályázatát „Hazánk mezőgazdasága diákszemmel" címmel. Az évek során beérkezett, változatos és értékes pályamunkák száma több ezerre tehető, a gazdag múlt pedig kötelez: 2012-től újraindítottuk pályázatunkat, ezúttal „Hétmérföld” elnevezéssel.

\section{Tárlatvezetés}

A Városliget által övezett épület kiállításainak mindegyikében a környezeti nevelés egy-egy alaptémájának történetét ismerhetik meg a látogatók a magyar mezőgazdaságot bemutató történeti kiállítástól az erdészetet, természeti értékeinket, növényeinket, halászatunkat, vadászatunkat bemutató kiállításokon keresztül a szőlőművelésig és lótenyésztésig. A pontos kiállításcímek a következők:

- A magyar mezőgazdaság története a kezdetektől 1945-ig.

- Az állatok háziasítása.

- „A növények országából...”.

- Erdészet.

- Természeti értékeink, természetvédelem.

- A magyar szőlő és bor Európában.

- Vadgazdálkodás és vadászat.

- A halászat története Magyarországon.

- A ló - nemzeti ló kiállítás.

Fentieket látva, a témaköröket ismerve tehát nem kell magyarázni, hogy tárlatvezetéseink is minden ízükben a környezeti nevelést szolgálják.

\section{Múzeumpedagógia}

Miért fontos a gyermekek számára a nálunk eltöltött idő, miért is hasznos a múzeumpedagógia? Különböző korosztályokra szabva ismertetjük meg velük a magyar mezőgazdasággal kapcsolatos emlékeket, tevékenységi köröket, életformákat, különös figyelmet fordítva a bennünket körülvevő környezet értékeire. Foglalkozásainkban szervesen összeolvadnak a környezet- és természetvédelem, a magyar mezőgazdaság valamint a néprajz szépségei, így látogatóink nemcsak a hagyományos gazda- és pásztoréletbe pillanthatnak be, de drámajátékaink során meg is személyesíthetik a régmúlt idők szereplőit.

Igényelhető, folyamatosan bővülő, kiállításainkhoz kapcsolódó múzeum- és drámapedagógiai foglalkozásaink általános iskolásoknak: 
- Búza, búza, búza, de szép tábla búza - a vetéstől a kenyérig

A kenyér az élet jelképe volt a parasztember számára, egész éves munkájának gyümölcse, amit az elvetett búzától a kenyér megszegésének pillanatáig végeznie kellett.

A foglalkozáson a mezőgazdasági munkákkal, elsősorban a gabonatermeléssel és a hozzá kapcsolódó népszokásokkal ismerkedünk. A kiállítás tárgyainak segítségével a gabonatermelés eszközeinek fejlödését is megvizsgáljuk.

Az éves mezőgazdasági munkák közül sorra vesszük a szántást, vetést, boronálást, aratást, végül a cséplést, nyomtatást. Beszélgetünk arról is, hogy régen milyen fáradságos munka volt a mindennapi kenyér megteremetése, ellentétben mai rutinjainkkal, életvezetésünkkel. A foglalkozáshoz kézi őrlővel végzett búzaőrlés tartozik.

- Kalandos pásztorélet - így éltek hajdanán a pásztorok

Mit is jelent a vasaló? Milyen készség vajon a pásztorkészség? Mire való a juhászkampó? Mire használták a rovásfát?

A foglalkozáson többek között választ kapunk a fent felsorolt kérdésekre, továbbá megtanuljuk, mely állatok terelője volt a csikós, a kondás, a gulyás és a juhász. Megismerkedünk mindennapi életükkel, étkeikkel, viseletükkel, használati tárgyaikkal és mindennapos munkaeszközeikkel.

Beszélgetünk az állatok kihajtásáról, a Szent György naphoz kapcsolódó szokásokról és a behajtásról. A kiállítás preparált állatainak és szobrainak segítségével feltérképezzük a hagyományos magyar állattartásban tenyésztett állatok színes világát (pl. magyar szürke marha, mangalica, racka juh).

- A babonák nyelvén - Múzeumi péntek 13 / Drámajátékos mühelymunka

Miért hordunk magunkkal kabalát, illetve különböző szerencsehozó tárgyakat? Vajon a péntek 13-a egy különösen szerencsétlen nap?

Már az ókori babonákban, később a keresztény vallásban, a népi hiedelmekben, a legendákban, a számmisztikában is találunk erre a napra való utalásokat. A népi hiedelmek szerint a böködős tehenek és a rúgós lovak péntek 13-án születtek, de a foglalkozás során megismerkedhetünk a „Kincsem (telivér versenyló, született: Tápiószentmárton,1874.) legenda" babonáival is.

A mühelymunka során megtudhatjuk mikor vethettek elődeink, melyik alkalmas időpontban házasodhattak, hová ülhettek az asztalnál. Söt, manapság is hasznos tudással gazdagodhatunk: mikor vegyünk be orvosságot, költözzünk új lakásba, mikor induljunk hosszú útra, mikor mehetünk fel a tetőre és mikor böjtölhetünk.

- Nemez van a fejünk fölött - Élet a jurtában

A foglalkozáson a honfoglaló magyarok ősi szálláshelyével, a kazah nemezsátorral ismerkedünk: a tér beosztásával, a női és férfi oldal használati tárgyaival, öltözékükkel, az oltár elhelyezkedésével és jelképeivel (égig érő fa: 
életfa vagy világfa). Továbbá az ősmagyarok hitvilágával (testlelkek, szabadlelkek és álomlelkek), a rovásírás technikájával és alkalmazásával, az emberfeletti erővel rendelkező sámánokkal, a honfoglaló magyarok harcmodorával, harci eszközeivel és a gyüjtögetés, tárolás és az egészséges táplálkozás fortélyaival.

A mühelymunkához kapcsolódik egy parányi régészkedés, rovásírás és kézmüves foglalkozás: nemezlabda, nemezkép- és nemezékszer készítés.

- „Nyitva áll az ajtó...” - elődeink hajlékai

Hogyan éltek őseink? Hogyan építették a jurtát? Miért a földbe építették a veremházat? Hogyan és miből készült a vályogfal és a boronafal? Másként építkeztek az eltérő földrajzi adottságú tájakon élő emberek?

Többek között ezekre a kérdésekre keressük a választ a foglalkozáson. Megismerkedünk a jurtaépítés folyamatával és annak szigorú rendet követő belső beosztásával. Beszélgetünk a veremházak felépítéséről, a vályogházak megjelenéséről, majd a többhelyiséges épületek szükségessé válásáról.

- Vadon élő állatok

A foglalkozáson a vadon élö állatainkkal ismerkedünk, mint például a gímszarvassal, őzzel, muflonnal, dámszarvassal, rókával és a mezei nyúllal. A Vadászati kiállítás preparált állatainak és a mögöttük látható diorámák segítségével beszélgetünk az állatok testfelépítéséről, táplálkozásáról, természetes élőhelyéről és érzékszervi sajátosságairól.

Felmérjük, hányan nyomunk a csoportból annyit a mérlegen, mint egy kapitális barnamedve, és mekkora egy sas szárnyfesztávolsága.

- Véka... (Az Árpád kortól 1711-ig, a későközépkorig)

A kalandozó hadjáratok kudarca után (honfoglalás: 896) a lovas nomád, harcos népből letelepedett, békés, de saját határait megvédeni képes néppé vált a magyarság és a környező királysághoz (Államalapítás: Géza fejedelem, Szent István) hasonló államformát alakított ki. A foglalkozáson az agyagtapasztással készült alföldi lakóházzal (XV. század) ismerkedünk, mely a középkori paraszti lakáskultúra legkorszerübb megoldása volt.

Megismerkedünk a kunyhószerü házakkal, melyek sárból, nádból és vesszőből épülnek, amelyeket szérüskertek, ólas kertek öveznek, a falusi háztartással és a gazdálkodás tárgyi emlékeivel, a késő-középkori táplálkozáskultúrával (erjesztett kenyér, kalács és a cserép főzőbográcsban fözött étkek), a 16. század paraszti kereskedelmével (szarvasmarha, bor és gabona), a török uralom idején használt új gazdasági eljárásokkal, újonnan megismert ízekkel (mandula és naspolya), állattartással (lúd, kopasznyakú és parlagi tyúk, juh), munkaeszközökkel (ültetőfa, véka, cséphadaró) és a híres Rákóczi-ekével.

- „Zaboló” - a lovak világa

Hozhat-e szerencsét a talált patkó? Mikor és hol használunk szénát vagy szalmát? 
A foglalkozáson a gyermekekkel különböző szerepekbe bújva a Kincsem Imperiál, Híres magyar versenylovak és A ló - Nemzeti ló kiállítás címü tárlatokat barangoljuk be.

A diákok megismerkedhetnek a lovak lehetséges színeivel és jármódjaival, a paraszti lótartással, az ősi mesterségekkel, a csikós, a kovács és a szíjgyártó munkaeszközeivel, a híres magyar versenylovak, Kincsem és Imperiál történetével, továbbá a ló ápolásának eszközeivel és a lovak gyógyításával. Felfedezhetik a lóversenyzés (az ügető és a galopp), a verseny előtt történő mázsálás, a suttogó lovas oktatás és a gyógyító lovaglás, a hippoterápia rejtelmeit is.

A kiállítás megtekintése után a gyermekek az egyénre szabott játékos feladatok megoldásáért szakértői oklevelet vehetnek át, mint zsokék, abrakmesterek, lógondozók, trénerek és lódoktorok. A versenylovak szerepébe bújt látogatóinkat az oklevélen feltüntetett helyezési díjjal jutalmazzuk.

Igényelhető, folyamatosan bővülő, kiállításainkhoz kapcsolódó múzeumpedagógiai foglalkozásaink óvodásoknak:

- A torony titka / Múzeumpedagógiai foglalkozás

A várkisasszony titokban, atyja intése ellenére a Vajdahunyadvár egyik tornyában járt, ahol elhagyta a brossát. Ha a palotaőrség megtalálja, lelepleződik. Segítsünk neki megtalálni az elveszett ékszert!

A várkisasszony közelébe azonban nem kerülhet akárki. Ezért a fiúknak lovagi tornán kell bizonyítaniuk rátermettségüket, míg a lányok az udvarház vezetésével ismerkednek. A próbák után lovaggá avatjuk az ifjakat, a leányok pedig társalkodónői, udvarhölgyi ajánlólevelet kapnak.

Hogy a soktornyú Vajdahunyadvárban el ne tévedjünk, megismerkedünk az épület történetével is. A foglalkozás végén a rózsaablak mintájára ólomüveg sütit sütünk.

- Nyuszi hozza? - Húsvéti jelképeink / Múzeumpedagógiai foglalkozás

Ugye elgondolkodtak már azon, miért nyuszi hozza a húsvétkor az ajándékot, és egyáltalán hogy tojhat tojásokat? Vajon miért barkaágat díszítünk húsvét táján, és miért éppen tojásokkal? Miért báránysült kerül az ünnepi asztalra? Mit takar a húsvét elnevezése, és miért változik az időpontja évről évre? Valójában mit is ünneplünk húsvétkor?

A múzeum kiállításaiban keresünk választ a fenti kérdésekre, megbeszéljük a húsvéti jelképeket, és ezek eredetét is megismerhetik a gyerekek a foglakozás során.

- Állatok a ház körül / Múzeumpedagógiai foglalkozás

Háziállataink nélkül nehéz lenne elképzelni mindennapjainkat. Gondoljunk csak bele, életünk mennyi területén nélkülözhetetlenek. Biztosan hiányozna télen a gyapjúsál melege, bajos lenne elkölteni a reggelinket tej, vaj, és sajt nélkül, a mézeskalács illata hiányozna karácsonykor, szappan híján gondban lennénk a fürdőszobában, és közel 100 éve még a közlekedés is megbénult volna lovas 
hintók és ökrös fogatok nélkül. Gyerekdalok, versek segítenek, hogy megtaláljuk a múzeumban a háziállatokat, miközben tudatosítjuk, melyiknek mit köszönhetünk. Tízóraira pedig igazi vajas kenyeret majszolunk.

- Hallgatag erdő, titkot rejtő - Vadon élő állatokról / Múzeumpedagógiai foglalkozás

A címben szereplő Gryllus Vilmos dal biztosan sok gyermeknek ismerős. A foglalkozás során egyre több titkát fedi fel nekünk az erdő. Egyedülálló életközösségébe pillanthatunk be a múzeum kiállításainak segítségével. Nemcsak az erdő nagyvadjaival (gímszarvas, őz, muflon, stb.), de az erdei dagonya apró élőlényeivel (pl. ebihal, csíkbogár, szúnyoglárva, unka, stb.) is megismerkedhetnek a gyerekek.

- Süssünk, süssünk valamit / Múzeumpedagógiai foglalkozás

Például kenyeret! No, de hogy lesz a búzából kenyér? A legnehezebb asszonyi munka, a kenyérsütés folyamatát kísérjük végig kiállításainkban. Egy közismert gyermekdal segítségével a gyerekek megismerik a kenyérsütés mozzanatait, eszközeit. Ezek közül néhányat ki is próbálunk, miközben a foglalkozás zárásaként közösen sütünk egy kenyérlepényt.

- Füben-fában orvosság / Múzeumpedagógiai foglalkozás

Hajdanán, ha valaki megbetegedett, a füvesasszonyhoz fordultak segítségért. A gyógynövények ismerete, gyüjtése nagy hozzáértést igényelt, nem foglalkozhatott vele bárki. A javasasszonyok pontosan ismerték a gyógynövények lelőhelyeit, a szedés, begyűjtés időpontját, felhasználásuk módjait.

A mesékben csodás gyógyulással találkozunk: Csipkerózsika és Hófehérke a királyfi csókjától ébredt fel álmából, Rózsa királyfit a forrasztófüvel kenegette, az élet vizével locsolgatta a lánykígyó, a vadász pedig hasmütéttel szabadította ki Piroskát és a nagymamát. De Ludas Matyi már gyógyfüvekért szalajtotta az udvar népét, hogy kikúrálja Döbrögi uramat. Mi ugyan nem csapunk fel udvari felcsernek, de néhány gyógynövényt mi is megvizsgálunk közelebbről, és abból készítünk gyógyteát. Egy-egy tea filtert haza is vihetnek a gyerekek az általuk összeválogatott gyógynövényekből.

- Adventi mézesbábos / Múzeumpedagógiai foglalkozás

„Nő a dér, álom jár, hó kering az ág közt, karácsonynak ünnepe lépeget a fák közt."

Advent ideje különleges időszak az év során, amikor az egyik legbensőségesebb ünnepünkre készülünk.

A foglalkozás során megbeszéljük az advent jelentését, időtartamát és jeles napjait. Énekelünk, verselünk, közben berendezünk egy kis betlehemet. Szóba kerülnek a karácsony jelképei, szokásai, ünnepi étkezése, nem feledkezve meg a mézeskalácsról sem.

Apropó mézeskalács! Ellátogatunk a méhészeti kiállításunkba is, ahol a gyerekek dióhéjban megismerkednek a méhek életével és a mézeskalácssütés régi 54 
eszközeivel, s befejezésül az elöre elkészített tésztából mézeskalácsot sütünk a gyerekekkel.

A várhoz és a Városligethez kapcsolódó foglalkozások, séták:

- A kiállításokhoz kapcsolódó múzeumpedagógiai foglalkozásainkon kívül „Nünüke, avagy nézd más szemmel a világot!” címmel új drámapedagógiai foglalkozást indítottunk útjára, mely kihasználva a kapcsolódó kiállításokat és a Városliget gazdag helyszíni adottságait, igyekszik a természet apró, gyakran észre sem vehető értékeire felhívni a gyerekek figyelmét.

- Emellett - ismét kilépve a múzeum falain - Vártörténeti sétákat tartunk, ahol a történelmünk építészeti stílusjegyeit felvonultató városligeti vár sejtelmes várfokainak, égbe emelkedő csúcsainak, pompázatos homlokzatainak történetét meséljük el, különleges esetekben pedig a Segesvári óratorony mintájára épített Apostolok tornyát „másszuk meg” a gyerekekkel. A vezetés során a magasból a panorámát, a közvetlen közelben látható épületrészeket, valamint távcsövekkel a Vajdahunyadvár távolabbi pontjain lévő épületszobrászati elemeket elemezhetik ki a résztvevők.

- Kortörténeti körsétánk során kiscsoportos felfedezőút várja a résztvevőket a vár körül, mely során távcsővel, iránytüvel, térképpel járják körbe a gyermekek az épületet. Vízköpőket, címereket és szobrokat vizsgálnak, miközben előkerülnek a Hunyadiak, Mátyás király fekete serege, Árpád-házi Szent Erzsébet, de még Drakula is!

- Ligeti sétáink alkalmából a várat és környezetét mutatjuk be a látogatóknak. A Városligetben található növényritkaságok között teszünk érdekes sétát a résztvevőkkel, akik olyan növényekről tudnak meg érdekességeket, mint a tiszafa, a magyal, az ostorfa, a platán, az enyves éger, a papíreperfa, a Ginkgo biloba, a füge stb.

\section{Zöld Óvoda pályázat koordinációja}

A 2000. évi XLIII. Hulladékgazdálkodási törvény kiadásával indult meg a Zöld Óvoda program kidolgozásának folyamata Magyarországon. A feladatok megvalósítását az Eötvös Loránd Tudományegyetem Tanító- és Óvóképző Főiskolai Kara végezte. A források megszüntével 2004 végétől a jogelőd környezetügyért felelős tárca Oktatási Osztálya folytatta az elindított folyamatot, majd 2005-ben elkészült a Zöld Óvoda 20 pontos kritérium- és indikátorrendszere. Ennek alapján 2006 áprilisától került sor a „Zöld Óvoda” pályázat lebonyolítására, mely feladatot a Vidékfejlesztési Minisztériummal közösen 2012 óta végezzük. A program célja az óvodákban folyó fenntarthatóságra nevelés szellemében történő nevelőmunka megvalósítása és fejlesztése; az óvodás gyermekek környezettudatos szemléletének, gondolkodásának, magatartásának megalapozása, formálása téralapú tevékenységek során; a pedagógusok, szülök, a helyi társadalom közösségei környezettudatosságának 
alakítása; a Zöld Óvodához tartozó térségi lakóközösségek értékeinek megismerése, azok fontosságának, védelmének tudatosítása a vidékfejlesztési elvek figyelembe vételével. A Zöld Óvoda címet 2006 óta hét alkalommal adták ki ünnepélyes keretek között, mellyel ma már több mint 800 óvoda büszkélkedhet.

\section{Rendezvények, oktatási programok}

Rendezvényeinken is igyekszünk felvonultatni azokat az értékeket, melyeket a hétköznapokon képviselünk, farsangkor, a jeles napokon, Márton napon vagy éppen a Múzeumok Éjszakáján is hangsúlyozzuk a környezettudatosság fontosságát, a természeti erőforrások védelmét különböző programelemek, foglalkozások, sajátos helyszínek kiválasztása vagy épp meghívott előadók közremüködésével.

\section{Lehetőségek tárháza a környezeti nevelés terén a Vajdahunyadvárban}

Titkos utazást téve a lehetőségek földjén olyan ötletek merülhetnek föl, mint: „Isten füves kertje” - gyógynövénykert kialakítása a Kerengőben; a jelenlegi Anonymus Étterem helyén Környezeti Oktatóközpont és Játszóház kialakítása; városi méhészet kiépítése az egyik toronyban; tanösvény létesítése a Széchenyi szigeten; a Városliget tavában a Millenniumi kiállításra kialakított Herman Ottó Halászfalu újjáépítése; új, környezeti neveléshez kapcsolódó kiállítások rendezése.

A fent felsorolt ötletek egyelöre valóban csak ötletek: csupán a Vajdahunyadvárban a környezeti neveléshez köthető lehetőségek sokféleségét kívánják érzékeltetni az olvasóval, pedagógusokkal és látogatókkal.

\section{Irodalom}

Balázs György és Oroszi Sándor (1996, szerk.) A 100 éves Mezögazdasági Múzeum. Magyar Mezőgazdasági Múzeum, Budapest. 